\title{
Semiotic Analysis of Moral Messages in Animated Film Raya and the Last Dragon
}

\author{
Afifah Ibna Fatina Tawakkal \\ English Literature Departement \\ Universitas Muhammadiyah Gorontalo \\ Indonesia \\ afifahtawakkal3005@gmail.com \\ Agnes Tasya Monix \\ English Literature Departement \\ Universitas Muhammadiyah Gorontalo \\ Indonesia \\ Emirson Watani \\ English Literature Departement \\ Universitas Muhammadiyah Gorontalo \\ Indonesia
}

Citation: Tawakkal, A. I. F., Monix, A. T., \& Watani, E. (2021). Semiotic analysis of moral messages in animated film Raya and The Last Dragon. Notion: Journal of Linguistics, Literature, and Culture, Vol 3(2), p. 105-111. http://doi.org/10.12928/notion.v3i2.4798

Article Info

Article History

- Article Received September $2^{\text {nd }}, 2021$

- Article Accepted October $30^{\text {th }}, 2021$

\section{Keywords}

Semiotics

Moral Messages

Animated Films
Raya and The Last Dragon is the latest computer-animated film from Walt Disney Pictures and Walt Disney Animation Studio. This animated film, directed by Don Hall and Carlos Lopez, tells the story of the adventures of a woman named Raya in saving the world. This journal article aims to analyze and describe the moral messages contained in the film Raya and The Last Dragon. This research uses qualitative methods, with Roland Barthes semiotics analysis approach, so that ultimately obtained the results of research on what moral messages contained in every dialogue spoken by each character such as moral messages about friendship, cooperation, responsibility, leadership, courage, unity, and most often appears in this film is the power of trust in each other to create unity without division. 


\section{INTRODUCTION}

Film industry continues to evolve over time as the age of technology and information grew. Film is one of the audio-visual literary genres that serve as a communication act that aims at transferring ideas, knowledge, thoughts and messages. The mass media in terms of understanding of mass communication are newspapers, letters, magazines, radio, television and film. The mass media are a very important component of society[8]. Basically in media studies, film shows are used as a tool to convey social, political, cultural and other messages. Messages in films use the mechanism of symbols that exist in the human mind in the form of message content, sound, words, conversations, and so on. Film does not only present the results of the creative process of an author but also provide messages and motivate the audience to reflect on problems that occurred in society. Film is one of the most effective media in delivering a message because it is easily accepted by the community[10].

Films are divided into several categories, including story films, news films, documentaries, and animated films. Animation comes from the word to animate which has the meaning of making as if alive and moving. So understanding of animation is the film comes from images that are processed in such a way turn into a picture move and talk[9]. The animated film industry is growing very rapidly and has also become a very popular mass media in the public because it has advantages in displaying various design products and is so attractive coupled with the stories and messages contained in films that can be used as lessons or motivation in our lives.

Today, Walt Disney is one of the largest and bestknown entertainment companies in the world, with fingers in almost every pie imaginable, from blockbuster science fiction to art films to princess movies[7]. Animated films are also no longer dedicated to children only but can be enjoyed by all people. In addition, animated films also present moral messages that need to be imitated by the audience, such as hard work, never giving up, helping each other, loving each other, and other moral messages.
Moral is the core element of literary works. The word moral is etymologically the same as ethics even though the original language is different, for that Moral can be interpreted as the values and norms that become a guide for a person or a group in regulating their behavior[5]. A moral message is a message or message of meaning contained in a story so that it can be an example or learning for someone who sees or hears it. Moral messages can be implied or explicit, through audiovisual, and audio-only, because moral messages are in a story that is packaged in forms, such as short stories, songs, poems, advertisements or films.

One of the 59th computer-animated films distributed by Walt Disney Pictures and Walt Disney Animation Studios America in 2021, directed by directors Carlos Lopeza Estrada and Don Hall is Raya and The Last Dragon. This film is basically the same as previous Disney films, such as Moana and Frozen about a princess who is destined to save the world. The animated film Raya and The Last Dragon Reflects on the social reality that is very slick in exemplifying the bad effects of human greed through the seizure of magic gems as a symbol of the struggle for power caused by greed, hatred, the desire for power to lead to divorce. On the other hand, trust is one of the human qualities to be conveyed in this film. Therefore, based on the study above, the researcher will analyze the Semiotics of Moral Messages in Animated Film Raya and The Last Dragon.

Semiotics is a scientific study or method of analysis to examine signs in the context of scenarios, images, texts, and scenes in the film. The word "semiotics" itself comes from the Greek, semeion which means "sign" or seme, which means "interpreter of signs". Semiotics plays a big role in interpreting many things. Learn sign means studying language and culture[1][2]. Semiotic analysis becomes one of the important sciences that must be mastered, in addition, it is for other analyzes in understanding the meaning/message in the discipline of communication, especially media texts

Semiotics is a broad diverse field that involves the study of multiple kinds of signs conveyed via varied channels and media, of socially organized and evolutionarily-generated sign systems, and of the 106 
conditions of signification or semiosis (i.e., the processes of making meaning from signs) [6].

Semiotic has many theories, such as Charles Sanders Pierce, Ferdinand De Saussure, and Roland Barthes[4]. So In this study, the researcher uses a semiotic analysis of Roland Barthes theory, which uses an emphasis on the meaning of a sign system through a first-level meaning system or commonly called denotation, then to a second-level meaning system called connotation and the last is in the form of revealing myths about signs as well as symbol.

\section{METHODOLOGY}

The Researcher used data collection techniques of descriptive qualitative research methods. Data analysis of qualitative descriptive research, unlike other qualitative approaches, does not use a preexisting set of rules that have been generated from the philosophical or epistemological stance of the discipline that created the specific qualitative research approach. Rather, qualitative descriptive research is purely data-derived in that codes are generated from the data in the course of the study. Like other qualitative research approaches, qualitative descriptive studies generally are characterized by simultaneous data collection and analysis[3].

The technique in analyzing the data, the researcher uses semiotic analysis of Roland Barthes theory, which uses an emphasis on the meaning of a sign system through the first level of meaning system or commonly called denotation, then to the second level of the meaning system called connotation and the last is the disclosure of myths about signs and symbols.

\section{RESULT AND DISCUSSION}

Departing from the analysis of the film Raya and The Last Dragon, this film tells the story of a brave girl from the land of Heart named Raya in searching for the last dragon, Sisu, to reunite the separated world, namely Kumandraa. By working together and trusting each other, Raya and her friends managed to save the world. They also realized that it was mutual trust in each other without any hostility that made them strong until they finally reunited to become Kumandraa.

The researcher will analyze the data that has been found in the film Raya and The Last Dragon, then analyse the dialogue spoken by each character and describe the utterances that contain moral messages. With Roland Barthes' semiotic theory approach that uses Denotation, Connotation and Myth, here are the data and results of the analysis of moral messages that were found :

"I believe that we can be Kumandra again, but someone has to take the first step"

Chief Benja advises Raya that their Land can reunited be Kumandraa once morebut their neighbouring kingdoms still insist on fighting for the dragon gemstones but Chip Benja believes that someone must take the first steps to initiate peace first.

Moral message: Don't be afraid to start the right think

" Listen to me! We have a choice, we can tear each other apart, or we can come together and build a better world"

Raya wanting to follow her father's faith in other people then she befriended the daughter of one of the leaders, Namaari, Then, Raya showed Namaari the dragon gem. But Namaari betrayed Raya.When the various kingdom has known where the Dragon Gem is hidden, they came and fought over the Gem. But Chief Benja breaks up the fight and gives them a choice whether they will continue to fight each other or make peace

Moral message: We are only as strong as we are united, as weak as we are divided

\section{"There's still light in this. There's still bope"}

The Dragon gem was destroyed because it was fought over and due to the destruction of dragon gem The Druun retrurned and attacked them. When Druun gets closer to Raya and Chief Benja is desperate because he can't run, while Raya continues to tell Chief Benja to keep running to avoid Druun but Chief Benja hopes more for Raya and the magic in the piece of Dragon gem to fight back The Druun,

Moral message: Never lose hope

“No, I can't just make another one"

Raya's journey in search of the last Dragon was successful. Finally, she managed to find the whereabouts of Sisu in the land of Tail, then woke 
Tawakkal, A. I. F., Monix, A. T., \& Watani, E. Semiotic analysis of moral messages in animated film Raya and The Last Dragon

Sisu who had been asleep for 500 years. Sisu was surprised because the dragon gem had been destroyed and the Druun attacked. Raya asked to Sisu if she could make one more dragon gem, but Sisu said that she couldn't make any more because the dragon gem was the result of combining the power of 5 dragons

Moral message: Don't waste your time on something you can't change

\section{"Anyone else wanna question why we're out here?"}

Warriors of Fang found the Raya accessories fallen in the land of the Tail so they stopped the search, but one of the Fang warriors said to Namari that Raya must have been attacked by Druun and turned into stone, he seemed to say not to continue the search for Raya so the warrior was slammed grounded by Namaari.

Moral meesage: Never doubt yourself

- Without proper protection, it would be a death sentence for our people"

- "Namaari, you're truly growing into the leader "

The Land of Fang was discussing expanding its territory, then one of the Fang's generals named Atitaya proposed to the chief Virana, the queen of the Fang to expand the area to the mainland where the area was controlled by Druun but on the advice of general Atitayawas rejected by the chief Virana because if they want to expand the area then must there is a solution to defeat Druun. then Chief Virana's daughter came and said to her mother that she had a solution to expand the territory so that her mother was proud of her

Moral message: To be a leader, you must be ready to take responsibility for your people

\section{"My girls Raya and I gonna fix the world "}

Sisu's identity that she is a dragon has been known by Raya's friends. Finally, Sisu convinced Raya's friends about their goal. Sisu is very confident that she will fix the world and save everyone who was turned into stone by Druun with Raya but the other friends also want to help Raya.

Moral message: Working together as a team is a key to success
- "Yeah, well, the world's broken, you can't trust anyone"

- "or maybe the world's broken because you don't trust anyone"

Raya comforted Sisu who was pensive because she had been lied to by a crafty chief of Talon then she said to Sisu "the world is broken, you can't trust anyone" especially since she was betrayed by Namari as a child then she didn't want to trust anyone at all, but the words were denied by Sisu, then she said "or maybe the world's broken because you don't trust anyone", actually It's not the world that has been broken but ourselves have thought badly. This is well and good that Raya shouldn't let what had happened with the dragon gem define her view of the rest of the people. But then came the part where the movie is pushing for Raya to put her growing trust to the one that had caused her pain and loss.

Moral message: The world is what you think of it, so think of it differently and your life will change, so never ever think bad for others

"We're world of orphans because people couldn't stop fighting over a gem"

Raya says to sisu that the world has been destroyed because everyone doesn't stop fight over the gems and fights happen just for selfishness as a result many people lose their families due to their greed

Moral message: Don't be greedy

"By proving to you that if you wanna get someone's trust you have to give a little trust first"

Arriving at The Land of Spine, Sisu ran ahead of Raya with a gift of food to give to Chief Spine. She wanted to prove to Raya that her assumption was wrong because she didn't want to trust anyone a gift is a form of trust to create confidence and comfort for each other

Moral message: If you seek trust, you must first give trust.

"I was born and bred to do only one thing. to invoke fear and to crush the skulls of my enemies"

when Raya and sisu had reached the bone they were entangled in the trap that had been prepared by the fangs. because Sisu who was in a hurry wanted to 
deliver a gift to the Chief Fang to refute his wrong principle. When Raya was in the trap room one of the Fang warriors named Tong came and bullied them into being afraid of him

Moral message: Don't afraid ofyour enemies because it will make them braver

"But my oldest brother Pengu refused to accept defeat, this is where we'd make our last stand, united, So, one by one they combined all their magic creating the Dragon Gem"

In the past, Sisu wasn't as gifted as her siblings. In the last attempt to save humanity, her siblings put all their power into a gem. This leaves her siblings to turn into stone from the Druun, leaving her to activate the gem and thus saving humanity. Even though she didn't understand why they chose her to survive in order to activate the gem, she knew that they trusted her and she trusted them.

\section{Moral message: Never give up}

"I don't know why they chose me. It could have been any of us. All I know is I trusted them and they trusted me. When they put their faith in me it empowered me beyond anything I could imagine"

After uniting the magic power of the four dragons into the gem, then was given to Sisu. Although Sisu is actually confused as to why her brothers chose her to use the gem to defeat Druun. But The other dragons put their trust in Sisu. They believed he could get the job done. Sisu didn't always believe in herself to that extent. However, the trust of other dragons strengthened him..

Moral message: Your belief in the members of your team will have the same effect. By believing in those you lead, you give them power beyond belief.

"It may feel impossible but sometimes you just have to take the first step even before you're ready, trust me"

Raya was discouraged. She distrusted people. She kept going back to her time of betrayal by Namaari. But at the same time, Namaari should be held accountable for what she had done and done the work to earn Raya's trust back. Starting by addressing the harm that she had caused her. When all you can do is take the first step to trust and hope for the best, hope is a good thing. But not yet in their situation. If Raya could see for herself that Namaari could be trusted again. Raya is desperate. He doesn't trust people. He keeps going back to the time of betrayal by Namaari but Sisu keeps trying to encourage Raya to get through the wound. To really change what went wrong. Therefore Raya just had to try.

Moral message: Be a forgiving person and don't be afraid to start the right think

\section{"I trust you, Namari"}

When Raya's meeting with Namari, Sisu confirmed that Namari was on their side. Sisu approached Namari but Namari instead pointed a gun at him but Sisu believed Namari that actually Namari was a good person so Sisu trusted her that Namari would not hurt her.

Moral message: Keep being kind to others

"She doesn't see us. Raya's blinded by her own rage"

Because Raya's trauma wasn't properly addressed, she wasn't able to trust Namaari when Sisu agreed to go with her. This caused her and Namaari to accidentally and gravely injure Sisu. With Sisu out of the count, it caused the waters to dry up and the Druun to become worse. Full of anger, she went to meet Namari and they both got into a fight. Boun calls out for Raya from a distance because Druun is coming to attack the people but Raya doesn't hear Boun's screams at all. Tong informs Boun that Raya won't hear Boun's screams as Raya is being overcome with anger unaware that the surrounding buildings have collapsed.

Moral message: Anger is like a flame blazing up and consuming our self-control, making us think, say, and do things that we will probably regret later

'I don't care if you believe in me. Sisu did. But you didn't trust her. That's why we're here. Do whatever you want. But you're as much to blame for Sisu's death as I am.

The plot was then arranged in a life-and-stone situation where the only way she could fix her mistake is to let go of her trauma and take the first step into trusting Namaari. Raya was then partly blamed for the dangers that ensued 
Moral message: Beware of hiding behind past hurts. Your past hurt will blind you to the alliances you can build today.

"It's not about her magic. It's about trust to finally trust each other and fix this, but we have to come together"

The incident 500 years ago repeated itself where the five dragons were surrounded by Druun and this time it happened to Raya and her friends. Raya asked her friends to join the shards of the gem together. They would have to trust one another, but Boun denied that the magic was gone even though they were put together because Sisu was dead. But Raya believes that this matter is not about magic but it is a matter of belief that they must unite and believe that they can definitely fight Druun like the Dragons used to do. Yet, she finally got the others to do it when she showed she now trusted Namaari. Then She stepped forward and handed her piece to Namaari.

Moral message: Trust is a huge deal. Without trust, organizations flounder. They have ripped apart because of people looking out for themselves rather than everyone.

\section{"Then let me take the first step"}

Namari's friends don't believe and doubt Raya's words, moreover their hatred for Namari they don't want to believe her at all, in the end, Raya knows that this will never work if no one starts it first by her, then she gives the pieces of dragon gem to Namari because Raya trusted her and forgave her mistake..

Moral message: Don't be afraid to start the right think, mutual trust, and forgive each other.

\section{"Chief Benja, your danghter did you proud"}

At last Raya, Sisu, and her friends managed to defeat the Druun and eliminate it from the earth because of unity and mutual trust to strengthen each other. So, they reunited and became Kumandraa once more. Raya met her father and hugged each other. Sisu approaches Chief Benja. She tells Chief Benja that his daughter did him proud. She bragged on Chief Benja's daughter.

Moral message: Great leaders take this one step further. They go to their team member's loved ones and tell them of the great work they've done. They brag on their team members to other people.

\section{CONCLUSION}

In this film, Sisu teaches us that a simple word of trust can unite worlds apart, and Raya, a girl who was traumatized by her childhood friend's betrayal but she learns to forget her pain and tries to be brave to forgive her past and trust to everyone. By working together and trusting each other, Raya and her friends managed to save the world. They also realized that mutual trust without any hostility made them strong, in the end all the land reunited to become Kumandraa.

After being analyzed using semiotic by Roland Barthes analysis, the researcher can conclude the moral messages in Animated film Raya and The Last Dragon contained through dialogues of each character in the film such as moral messages about friendship, cooperation, responsibility, leadership, courage, unity, and most often appearing in this film is the power of trust in each other to create unity without division.

This message touches on the social reality of division and social conflict caused by prejudice, hatred, greed, and the desire for power. This film seems to want to say that it is time for humans to introspect each other than end hostilities to create peace on this earth.

\section{ACKNOWLEDGMENT}

The author realizes that this research could not be completed without the help, support, guidance, and advice of my English teacher, Dahlia Husain, S.pd, M.Hum and Ana Mariana, M.pd. Without them, this research could not be completed as the author hoped.

\section{REFERENCES}

[1] Faizal, M., \& Barliana, S. (n.d.). Pendekatan semiotik model roland barthes dalam karya sastra prancis 1 .

[2] Ibrahim, I., \& Sulaiman, S. (2020). Semiotic Communication: An Approach of Understanding a Meaning in Communication. International Journal of Media and Communication Research, 1(1), 22-31. https://doi.org/10.25299/ijmcr.v1i1.4584 
[3] Lambert, V. a., \& Lambert, C. E. (2013). Qualitative Descriptive Research: An Acceptable Design. Pacific Rim International Journal of Nursing Research, Vol 16(4), p. 255-256. http://www.antispam.kmutt.ac.th/index.php/P RIJNR/article/download/5805/5064

[4] Murtaisah, D. (2020). Semiotics analysis of meme for woman at@9gaggirly instagram account. http://www.etheses.uinmalang.ac.id/22011/1/15320195.pdf

[5] Nugraha, S., Suhendar, J. S., \& Fauziya, D. S. (2019). Analisis Unsur Intrinsik Dan Nilai Moral Dalam Cerpen "Mengapa Orang Gila Membunuh Ustaz?" Karya Faris Alfaisal Pada Surat Kabar Republika Edisi 1 April 2018. Parole (Jurnal Pendidikan Bahasa Dan Sastra Indonesia), Vol 2(1), p. 115-122.

https://www.journal.ikipsiliwangi.ac.id/index.ph $\mathrm{p} / \mathrm{parole} /$ article/view/1995

[6] Prior, P. (2018). Semiotics Semiotics. July.

[7] Meyer, A. (2016). Digital Commons @ SPU Animation or Cartoons: An American Dilemma.

[8] Ramani, C. V. (2018). Mass Media and Its Role in Enhancing Students English Language Skills. International Journal of Innovative Research and Advanced Studies Vol 5(1), p. 154-157. http://www.ijiras.com/2018/Vol 5-

Issue $1 /$ paper 27.pdf

[9] Nadya \& Sari, Y. P. (2019). Analisis Visual Penerapan 12 Prinsip Animasi Dalam Film Grey \& Jingga: the Twilight Animated Series Episode 1. Jurnal Titik Imaji, $\mathrm{Vol} 2$, p. 80-86. https://journal.ubm.ac.id/index.php/titikimaji/article/view/1955

[10]Septiani, D. L., Rejeki, S., \& Widisanti, N. M. W. (2019). The relationship between symbol and meaning in the film ZOOTOPIA. Journal Albion: Journal of English Literature, Language and Culture, Vol 1(1), p. 41-50. https://journal.unpak.ac.id/index.php/albion/ar ticle/view/1120/964 